\title{
Socialismo e História no Pensamento Político de Antero de Quental
}

\author{
Socialism and History in Political Thought of Antero de Quental
}

\author{
Flávia Rodrigues Bittencourt \\ Mestranda em História Social pela \\ Universidade de São Paulo \\ flaviabitt@usp.br
}

Resumo: Como um dos principais atores da geração portuguesa de 1870, Antero de Quental interpretava a ordem social em que estava inserido como socialmente injusta e incapaz de promover igualdade. Buscando respostas a fim de solucionar os problemas decorrentes das contradições sociais, econômicas e políticas, o letrado identificou no socialismo um meio para a efetivação da igualdade social. Para tanto, e para legitimar seus ideais, Antero valia-se das teorias revolucionárias propagadas pela Primeira Internacional, e da história como pressupostos de seu pensamento. Nesse sentido, é objetivo deste artigo desenvolver como o letrado concebia o socialismo enquanto teoria e como a história constituiu-se como argumento essencial para suas concepções políticas.

Palavras-chave: Antero de Quental, socialism, história.

\begin{abstract}
In the 1870s, Antero de Quental, one of the main portuguese writers, believed that the society he lived in was unfair and unable to promote social equality. While he was seeking answers to solve the problems arising from the social, economical and political contradictions, the literate identified the socialism as a means to achieve the social equality. In order to prove and legitimate his values and concepts, Antero was based on revolutionary theories from the First International and in history, so it could also serve as a basis for his arguments. The objectives of this article are to understand the meaning of the Socialism from Antero's point of view and the importance of History creating Antero's political concepts and theories.
\end{abstract}

Keywords: Antero de Quental, socialismo, history. 
Na década de 1870, Antero Tarquínio de Quental (1842-1891) destacou-se como um dos principais intelectuais de sua geração. Nela, aspirações e tendências, como o republicanismo e o socialismo, eram fortemente defendidas e movidas pelos ideais de justiça, de igualdade e de moral ${ }^{1}$. Os jovens setentistas compartilhavam e sentiam uma revolta frente às injustiças sociais, interpretadas como desdobramentos do liberalismo clássico que havia falhado com a igualdade e com a justiça. Nesse sentido, e com o desenvolvimento do socialismo científico, principalmente no contexto internacional, os jovens passaram a acreditar no socialismo e na valorização da república (SERRÃO, 1979: 23-24).

Antero de Quental como um dos mentores desse movimento que consagrava jovens intelectuais engajados politicamente (MEDINA, 1984: 17-19) na opinião pública, colocava seu pensamento socialista como proposição política a fim de superar as contradições sociais características dos regimes liberais. Visava, ainda, desenvolver uma teoria política igualitária, conforme as teorias revolucionárias e sociais do período.

Para Antero, a natureza havia criado homens livres e iguais, a forma de organização social, porém, fez com que se afirmassem duas classes inimigas de opressores e oprimidos, capitalistas e proletários. O Socialismo apresentava-se como um produto dessas contradições, defendido pelos homens que se contrapunham à miséria e à desigualdade social. O fator central que contribuía para a desigualdade era o modo de distribuição do capital que, apesar de ser fundamental para a produção e o progresso, estava concentrado nas mãos daqueles que monopolizavam os instrumentos de trabalho. A sociedade estava dividida entre os que produziam e os que precisavam dessa contribuição produtiva para angariar lucros.

“A concorrência e o salário põem o trabalho à mercê do capital: e este, sentindose forte, extrai do trabalhador tudo quanto ele produz, deixando-lhe apenas o suficiente para não morrer, isto é, para poder continuar a trabalhar!” (QUENTAL, 1982: 333). Tratava-se de roubo, o trabalhador produz pelo seu esforço, mas não se apropriava de sua produção. Isso, conforme os critérios científicos da economia, do ponto de vista de Antero, não estavam de acordo com a justiça.

\footnotetext{
${ }^{1}$ A moral na concepção anteriana relacionava-se aos princípios socialistas defendidos pelo autor e por alguns intelectuais de sua geração, sendo assim, a utilização do termo poderia, na perspectiva de Antero, representar uma contraposição aos ideais do liberalismo do início do século XIX e da monarquia constitucional.
} 
Em relação à justiça, Antero acreditava que tudo o que havia sido produzido pela humanidade teria que ser considerado de todos e o que fosse produzido pelo esforço do indivíduo seria considerado como propriedade individual. O letrado diferenciou a propriedade individual da coletiva numa lógica que buscava a superação da ordem real injusta. Para ele, essa separação estaria nos conformes das leis naturais (SARAIVA, 1995: 54), ou seja, das leis que independem das instituições políticas, esta fundamentação equivale ao jusnaturalismo anteriano.

A solução para as contradições econômico-sociais viria do coletivismo:

[...] um sistema, que, ao mesmo tempo que garanta a cada qual o pleno direito da sociedade individual, filha do seu trabalho, arranque todos os capitais ativos - isto é, os instrumentos do trabalho - ao monopólio dos indivíduos, e faça deles o que devem ser, patrimônio da humanidade, ao dispor de todos os trabalhadores. [...]; isto é a justiça social. Que todos trabalhem livremente, e que ninguém tenha o poder de impor condições e de levantar tributo ao trabalho alheio, tal é a base da nova concepção de economia das sociedades, firmada na distinção fundamental entre a propriedade individual e a propriedade coletiva (QUENTAL, 1982: 339).

Para o estabelecimento da equidade social e econômica Antero propunha a descentralização do capital, ou melhor, a gratuidade do capital de produção. Por esse critério, que no entender de Antero seria a manifestação da justiça, poderia ser alcançada a igualdade de condições por meio da desapropriação. O coletivismo foi a base principal do pensamento anteriano, princípio no qual iria radicar o seu pensamento socialista, tanto em termos estruturais nas relações econômico-sociais, como em termos da superestrutura proposta. Através do coletivismo, Antero pensou o trabalho e, portanto, o trabalhador, o povo, aqueles que eram vítimas do sistema burguês, passíveis de alienação nas relações de produção.

Afinal, quais são os argumentos nos quais o letrado se apoiou para acreditar numa profunda e efetiva revolução social? Em síntese, suas fundamentações se resumem em duas, as circunstâncias históricas, que a seu ver seguiam a lógica evolucionista/progressista, e a racionalização das teorias sociais com base científica que articulava a história com o devir. Tanto o progresso como as teorias sociais caminhavam juntos para a efetivação de uma sociedade justa. Assim como algumas correntes da época, Antero também acreditava na libertação social que estaria inscrita na história. 
Antero de Quental sensibilizou-se quanto aos aspectos históricos e sociais que se desdobraram em contradições e explorações, mas também ele identificou nas novas manifestações típicas de seu século fatores que apontavam para uma nova demanda organizativa da sociedade.

Os fenômenos sociais dos últimos dois anos, a força e espontaneidade do movimento operário que irresistivelmente se desenvolve e propaga, um novo espírito que acorda no povo trabalhador e cuja influência se faz sentir e se manifesta numa parte da pequena burguesia e na mocidade estudiosa, estes novos fenômenos da sociedade portuguesa vieram dar razão aos nossos íntimos pressentimentos e mostrar-nos que não confiáramos e nem esperáramos em vão. Fatos [...] como as conferências democráticas; como o aparecimento de uns poucos de jornais republicanos e socialistas; como as últimas greves e o espírito que nelas se manifesta: fatos tais são por si bem significativos: para quem tem os olhos abertos e a inteligência aberta (QUENTAL, 1982: 386).

O Socialismo para Antero manifestava-se como uma demanda histórica, expressa pelas aspirações populares e problematizada, cientificamente, por intelectuais. A racionalização da revolução social no pensamento anteriano se mantinha na linha tênue entre o conhecimento científico, limitado a relacionar os fenômenos, e a lei da evolução, atribuída de naturalismo. O conhecimento científico, que articulava as circunstâncias históricas, mostrava que a sociedade poderia ser transformada através de suas leis orgânicas, como qualquer organismo. $O$ processo mais adequado para a sua transformação seria a substituição gradativa de alguns elementos sociais que estabelecessem um novo equilíbrio de forças, sem ser de forma brusca (CATROGA, 1992: 29-30).

Essa maneira de se pensar a transformação social, em que pese à evolução "pacifista" a fim de extinguir as classes sociais e estabelecer a igualdade, traduz a ideia fundante da Primeira Internacional (SARAIVA, 1995: 55). As ideias de Antero foram majoritariamente baseadas numa perspectiva internacional/universal, desde sua apropriação dos conceitos de República e de Socialismo² até os seus apontamentos sobre

\footnotetext{
${ }^{2}$ Após a comuna de Paris houve repressão na Espanha em razão das ideias propagadas pela Associação Internacional dos Trabalhadores. Em 1871, os espanhóis Mora, Morago e Anselmo Lorenzo chegaram a Portugal onde não havia nenhuma organização que correspondesse ou se ligasse a Internacional. No
} 
as circunstâncias sociais favoráveis à legitimação política do Socialismo (SARAIVA, 1995: 52). Nesse sentido foi que Antero se apresentou como porta voz e precursor do Socialismo da Primeira Internacional em Portugal. Não negava os acontecimentos internos de seu país, deixando isso claro em Causas da decadência dos povos peninsulares $^{3}$, mas é significativo como tanto as teorias como os fatores externos o influenciaram na formulação de sua teoria.

Portugal era parte integrante na noção cosmopolita e revolucionária de Antero, mas não era o seu único ponto de reflexão. Antero de Quental era um humanista, e como tal pensou a Humanidade sob uma perspectiva pluridimensional, fosse para analisar criticamente as contradições reais, fosse para pensar uma nova forma de reorganizar socialmente as diferenças com a finalidade de se estabelecer a igualdade de condições.

Para o letrado, independentemente de a organização social ter favorecido as tensões sociais, era no direito naturalmente igualitário que ele se fundamentava. Dessa contradição social derivam as aspirações para o socialismo contemporâneo, pois elas eram o protesto dos que sofriam. Os que defendiam o ideário socialista, que clamavam a igualdade, tinham por base o direito natural e inalienável que o homem possui à vida, ao bem-estar e à instrução (QUENTAL, 1982: 331).

Entre os teóricos socialistas, era comum recorrer à crítica da realidade concreta para legitimar a revolução social. Assim fez Karl Marx quando se contrapôs à lógica da economia política, e Proudhon em relação à propriedade privada, no entanto, salvo as respectivas diferenças conclusivas, ambos foram direcionados pela concretude das contradições sociais. Intelectual atento a essas teorias, Antero se aproximava desses filósofos no que se refere ao método analítico, apesar de também ter elaborado suas próprias conclusões.

Adepto dos critérios científicos, o letrado enxergava na ciência elementos para a racionalização da política. Para ele, o saber científico de seu tempo via o modelo antigo revolucionário, como as revoluções liberais do início do século, como absurdo, sistemático e intratável. Em contraposição, a solução estava no novo revolucionário,

entanto, foi através das associações operárias que os espanhóis se aproximaram de Antero, eles explicaram ao letrado a diferença entre republicanos e socialistas que até então eram termos que se confundiam. Durante uma reunião na casa de Antero foi resolvida a fundação da seção portuguesa da Internacional que permaneceu marcada pelas origens espanholas e proudhonianas.

${ }^{3}$ Nas chamadas Conferências Democráticas do Casino, uma proposta dos jovens da Geração de 70, tinhase a finalidade de elevar a consciência pública portuguesa sobre os acontecimentos nacionais e internacionais. O programa não pôde ser concluído, pois as conferências foram proibidas pelo governo. Entretanto, essa proibição foi depois de Antero de Quental ter ministrado a primeira conferência intitulada Causas da decadência dos povos peninsulares. 
pautado na ciência e na crítica, pois a revolução não era um simples tema de raciocínios abstratos, antes, o revolucionário tinha que tratar no terreno das realidades, da observação e da ciência, a partir de um viés objetivo, porque sem ele haveria utopias e não revolução (CATROGA, 1992: 28).

Antero defendia a construção da conscientização pelo debate, manteve uma postura otimista frente ao debate teórico da Internacional, mais especificamente no Congresso de Haia (1872). Para ele, o fato de terem sido apresentadas e discutidas correntes diversas, provava a extensão e a vitalidade das vertentes socialistas, sem haver uma unidade mecânica e artificial e sim uma organização harmônica, com elementos distintos, mas que se completavam, concorrendo para um resultado comum (QUENTAL, 1982: 378).

Acredita-se que ao afirmar a validade do cientificismo proposto pela Internacional, o letrado estivesse contrapondo-se às correntes teóricas, tanto as liberais como as incipientes tendências que defendiam a revolução socialista desde o início do século. Em 1875, Antero salientava que o momento era de "crítica positiva e de desenganos revolucionários, os profetas e reformadores vão sendo substituídos, nas preferências da opinião, pelos homens de ciência e pelos críticos" (RAMOS, 1992: 517 518). Como a sociedade era vista como um organismo com suas próprias leis, "a revolução havia de copiar a profunda naturalidade da evolução" (RAMOS, 1992: 517518). O apego à ciência dispensava o levante da bandeira vermelha (RAMOS, 1992: 518). Até o Congresso de Haia ainda não havia vingado a orientação monolítica do marxismo, esta coexistia com o núcleo de orientação libertária, representado por Bakunin e Proudhon, tendências doutrinárias estruturadas na descentralização e na autonomia atribuída aos núcleos internacionais (SARAIVA, 1995: 51), às quais se convencionou chamar de Socialismo anárquico. Ao descrever a distinção entre a propriedade individual e coletiva, Antero deixava claro de qual linha doutrinária se aproximava.

Assim como sua postura quanto à descentralização do capital na ordem estrutural, também na esfera da superestrutura o letrado defendia a descentralização através de federações de ofícios que representariam seus respectivos membros de interesses em comum.

O coletivismo seria o meio para alcançar o equilíbrio entre os interesses individuais e coletivos, sua regulamentação em instituição seria pela Federação agrícolaindustrial. Com base nesse organicismo, Antero buscava anular a distância entre o indivíduo e o Estado, para tal a Federação seria a sociedade política-econômica ideal, 
promovendo a descentralização através da representação por camadas sociais intermediárias. É neste sentido que o autor criticou o parlamentarismo e o voto universal: sendo a sociedade orgânica, suas instituições deveriam ser condizentes a esta condição, não uma forma abstrata, tinha que ser natural, não matemática (CATROGA, 1992: 4-5). Nas Federações, as Seções compactuariam e combinar-se-iam, não haveria poder deliberativo de uma sobre as outras. A Associação seria o pacto federal das Seções e de todos os membros. Nesse sentido, o princípio autoritário e centralizador desapareceria, “[...] é já um modelo de liberdade e igualdade da futura república democrática social" (QUENTAL, 1982: 346).

A Federação seria constituída por associações produtoras e consumidoras, com um sistema de crédito mútuo e gratuito, direcionada pelos princípios do coletivismo. Assim se extinguiriam as raízes nocivas do velho mundo, graças ao Socialismo, "perante a uma organização social, racional e equitativa não pode haver privilégios legais", a desigualdade só estaria nas diferentes atividades, na energia e na vontade. Sem o monopólio capitalista todos trabalhariam, e sendo o capital gratuito e universal, as condições de trabalho seriam iguais (QUENTAL, 1982: 341).

É significativo como o letrado conseguia articular princípios da ordem liberal, dados pelo individualismo, com a nova ordem científica que estava sendo proposta, unindo os interesses individuais aos coletivos. Esse tipo de reflexão possibilita afirmar que ele se esforçava para manter-se afastado de uma teoria que poderia ser interpretada como utópica, por isso manteve um perfeito diálogo com o liberalismo clássico da primeira metade do século XIX. Suas reflexões são características de um período de transição, mesmo que fosse, acentuadamente, no plano das mentalidades, das teorias.

Antero pretendia levar essa consciência às camadas trabalhadoras, no entanto, a prioridade não seria uma consciência de classe com a finalidade de se estabelecer uma guerra, mesmo porque o fim último do Socialismo era justamente acabar com as camadas sociais, a finalidade seria a elevação de uma consciência socialmente justa, através da prática coletivista, como um preparo para a ordem vindoura.

Caberia às Federações combinarem os esforços coletivos, enquanto que as Seções trabalhariam para uma "educação popular", para "educar socialmente" nos conformes democráticos tal que os trabalhadores, pela gerencia e estudo de seus interesses, reivindicando seus direitos, pudessem adquirir a consciência de sua posição. Nesses termos, eles poderiam se relacionar com todas as esferas da economia social, tornandose capazes de viver uma vida própria, com ideias próprias independentemente da proteção 
e do patronato em que viviam até o momento, nas condições de servos (QUENTAL, 1982: 346).

A elevação da consciência significou para Antero um princípio fundamental no processo de transição para a sociedade reformada. O Socialismo aflorava na história como um sistema legítimo por estar de acordo com a evolução e com os direitos naturais, assim também o era a consciência, ela teria que fazer parte desse mesmo processo, porém, contando ainda com o aparato científico que em termos práticos se manifestaria nas Seções de ofício. O letrado afirmava que a consciência seria desenvolvida gradualmente, no cotidiano, através da organização democrática e das greves. Assim sendo, o proletário sentiria a necessidade de mudança de forma consciente, não apenas pelas suas necessidades econômicas, como estava sendo na sociedade liberal através da subsistência devido ao roubo de sua produção e do consequente salário mínimo. A revolução viria organicamente.

"Não: não é revolucionariamente, e duma hora para a outra, que uma tão vasta transformação, que abrange todas as relações dos homens em sociedade, se pode efetuar" (QUENTAL, 1982: 343). Teria que haver então sucessivas transformações, uma lenta preparação visando educar os homens para a nova ordem, fazendo com que fosse possível uma transformação sem caos. O proletariado, a quem interessava a renovação (emancipação), só seria digno de gozar desses resultados quando, por meio da união, dedicação e virtude, os tivesse tornado possíveis.

Para a justiça ser conquistada teria que haver um preparo prático com liberdade, ciência e razão, ela seria um desdobramento da capacidade do indivíduo de pensar o social, o coletivo, de uma maneira que visasse a transformação geral em prol do "Bem em acto". Tendo isso, pressupõe-se que Antero não atribuía ao Estado, independentemente do tipo de regime, exercício equivalente ao que caberia e era pertencente ao indivíduo por natureza, "a liberdade e a razão em que ele se consubstanciaria". Como federalista, o letrado não almejava somente a destruição do Estado isso só não bastaria (SERRÃO, 1980: 353).

Só amaldiçoamos uma coisa: a perversão do que é, por natureza, bom, fecundo e necessário. O estado autoritário e capitalista é o nosso inimigo, e desejamos vê-lo destruído. O estado mutualista, a federação livre do trabalho de todos, esse é o nosso ideal, amamo-lo como a expressão da verdade no meio da sociedade (QUENTAL, 1982: 373). 
Para o letrado, o Estado representava a ponderação e o progresso dos interesses gerais, "é a equilibração total das forças da coletividade [...], o órgão correspondente à função dos serviços comuns" (QUENTAL, 1982: 372-373). Se o Estado se baseasse na propriedade justa ao invés da anarquia e se ele se movesse nos conformes da liberdade, utilizando-se de seu mecanismo natural; e se ao invés da economia anárquica, houvesse a harmonia dos interesses solidários entre os que trabalham e produzem (coletivismo), a política poderia passar da escola de "corrupção, desordem e ceptismo [para a] revelação evidente da ordem e da harmonia que reinam na coletividade" (QUENTAL, 1982: 372373). Caberia ao Estado tão somente respeitar a ordem natural e justa, expressa pelo exercício do coletivismo e que catalisaria e articularia os interesses individuais e os interesses coletivos, promovendo o bem-estar social.

A teoria anteriana sobre como o Socialismo teria que se manifestar em sociedade, baseou-se fundamentalmente no que o letrado acreditava ser moral e justo, respeitando o direito individual desde que este não menosprezasse ou fosse nocivo ao desenvolvimento da humanidade. Antero entendia a sociedade em suas partes específicas e diversas, mas acreditava na coligação pacífica dos diferentes interesses como meio favorável ao progresso político, econômico e social.

O fator histórico e as teorias revolucionárias, aliadas ao cientificismo, levaram Antero de Quental a concluir que as circunstâncias, apesar de injustas, caminhavam num sentido evolutivo para a igualdade, para o bem-estar humano. Assim como o letrado, outros intelectuais e filósofos conceituados acreditavam nessa tendência evolucionista, fosse ela por meios pacíficos ou pelo jacobinismo oriundo da Revolução Francesa (17891799). Atento às tendências do seu século, Antero compartilhou das grandes movimentações internacionais oitocentistas como crítico e como partícipe dos debates.

Como um dos precursores das ideias socialistas em Portugal, o pensamento político de Antero de Quental baseou-se essencialmente nas teorias divulgadas e problematizadas pela Associação Internacional dos Trabalhadores. Inegavelmente a influência da circunstância internacional foi um dos fatores determinantes para que o letrado desenvolvesse suas concepções políticas. Entretanto, não se pode desconsiderar que Portugal, apesar de constituir-se como parte do pensamento universalista do letrado, lhe era o ambiente próximo, onde obteve sua formação intelectual e onde pôde, através da crítica da realidade concreta, adquirir uma sensibilidade acerca das contradições sociais respectivas de seu país. 
Favorável ao debate público como um dos meios de elevar a consciência frente às grandes questões de seu tempo, em 1871, o letrado foi um dos mentores das Conferências Democráticas do Casino. Nelas, abriu-se um espaço para que fossem refletidos os problemas do atraso português ante o avanço da modernização europeia e as possíveis soluções a fim de promover o progresso do país. Sobre o programa dos conferencistas, Antero escreveu ao também intelectual Teófilo Braga:

Temos um programa, mas não uma doutrina; somos associação, mas não igreja: isto é: liga-nos um comum espírito de racionalismo, de humanização positiva das questões morais, (...) O nosso fim é produzir uma agitação intelectual na nossa sociedade, lançando em cada semana uma ideia ou duas para o meio desta massa adormecida do público (QUENTAL, 1984: 69. Grifos do original).

Nesse sentido, a análise feita por Antero em sua conferência, Causas da decadência dos povos peninsulares, e sua indignação quando as Conferências foram proibidas, contribuem significativamente para a compreensão de seu socialismo na medida em que é possível identificar seu senso cientificamente crítico quanto às contradições reais e como essas mesmas contradições legitimavam a reforma social.

Adolfo Coelho, contemporâneo de Antero e um dos conferencistas que tratou sobre o tema do ensino português, após a proibição das conferências, descreveu a possível motivação que fez com que o Marquês de Ávila e, portanto, o governo, tomasse determinada atitude. Segundo Coelho, Ávila acreditava que:

(...) as Conferências democráticas, a de Antero e a minha, constituíam o ensino de proposições condenadas pela Igreja do Estado, e quando dias depois da minha conferência, feita 20 dias após a de Antero, nos dirigíamos para o Casino, estando anunciada outra conferência, (...), achamos a porta fechada, estando nela afixada cópia da portaria que proibia a continuação dessas Conferências (COELHO, 1984: 77. Grifos do original).

De 1868 a 1871, António José de Ávila presidiu o Conselho do governo reformista do partido dos regeneradores que estava no poder. Os regeneradores tendiam a ser mais moderados, valorizavam reformas econômicas, administrativas e sociais, entendiam 
ainda que a centralização política e administrativa era essencial para o progresso em termos de riqueza, do desenvolvimento industrial e para o equilíbrio da coesão nacional (RIBEIRO, 1998: 102-103). Desde 1851, quando a questão da regeneração portuguesa foi oficializada, o partido vinha se fortalecendo, porém, a ação regeneradora tendia a se concentrar em reformas políticas e econômicas, na modernização e no desenvolvimento material do país. Sua tendência centralizadora apegava-se aos princípios da monarquia constitucional. Essa política voltada para questões materiais era entendida por Antero como favorável aos privilégios e à aristocracia do dinheiro e da propriedade, fazia parte da revolução burguesa.

Em carta aberta ao Marquês de Ávila, Antero se referiu à portaria que mandou fechar as salas onde eram ministradas as conferências como sendo uma atitude tola e contrária "à lei e ao espírito da época" porque era um atentado contra a liberdade do pensamento, da palavra e da reunião, direitos que fazem de uma sociedade idealmente humana. Indignado com a atitude do governo, Antero ressaltou ainda que "um ministro constitucional não podia prever estas excentricidades. V. Ex. ${ }^{a}$ obrou como quem é: nada mais. Quase que sinto desejo de o aplaudir" (QUENTAL, 1982: 302-303).

Tratava-se de uma manifestação explícita, a crítica de Antero à pessoa ministerial que foi o Marquês se estendia a todo o aparato institucional do regime contrário ao debate público. No entanto, por ser um governo constitucional, os homens de governo tinham a concepção errônea de que estavam agindo conforme os princípios liberais.

O que é a lei? É a opinião armada, nada mais. O que é a opinião? É o espírito da sociedade em que vivemos. Os estadistas ingleses são filósofos: a Inglaterra é um grande povo. V. Ex. ${ }^{a}$ não é um estadista inglês (QUENTAL, 1982: 304).

Isso dizia Antero ao comparar o significado da portaria em Portugal com o modelo legislativo inglês, acrescentando ainda que este dispunha de leis anteriores e que agregava diferentes interesses sociais, mas que a cada circunstância histórica adaptava a legislação de acordo com a opinião pública. Ao colocar a Inglaterra como referência de um liberalismo aqui entendido como democrático, acredita-se que Antero fazia menção ao sistema de coligação bipartidário de Portugal, mostrando que, apesar dos partidos terem ideários diferentes, seguiam juntos em busca do desenvolvimento restritamente material. 
O desenvolvimento das relações partidárias em Portugal fazia parte da tentativa de reproduzir no sul europeu o equilíbrio que se tinha na Inglaterra em relação à disputa parlamentar. Para tanto, quem governasse deveria resistir à tentação de monopolizar o poder ou agir de forma intolerante. Nesse sentido, para o estabelecimento da paz política e do progresso, as ideologias não foram aviltadas, governava-se junto às correntes contrárias (RAMOS, 1992: 484). No âmbito social, a tentativa de elevar a opinião pública, só se manifestou com a geração de 70 , através dos socialistas e dos positivistas que se desprendiam do transformismo de ideologias estéreis.

Esse tipo de política entre os partidos estava em processo desde 1851 e, até 1868, não teria havido rotativismo partidário e sim identificações e insuficiente organização partidária para o exercício da alternância no poder. A oficialização da fusão entre os partidos foi feita em 1865 através das eleições locais com a vitória dos representantes da coligação, mantendo-se até 1868 (RIBEIRO, 1998: 104).

Durante esses três anos, de 1865 a 1868, Antero esteve envolvido no polêmico embate acadêmico conhecido como Questão Coimbrã ${ }^{4}$; foi a Paris e a Espanha, onde adquiriu experiência como proletário e manteve contato com socialistas; e, já em Portugal com outros intelectuais, formou o Grupo do Cenáculo. Seu senso crítico havia passado por um processo de transformação que resultou em 1871 nas Conferências Democráticas e nas suas críticas ao Marquês de Ávila e à monarquia constitucional.

Nesse momento as interpretações sobre os acontecimentos na França ganhavam espaço na imprensa portuguesa. Havia os que atacavam, como os constitucionais e os católicos, e os que defendiam, os progressistas, que nesse período eram os jovens da geração de 70. As Conferências foram consequência do impacto da Comuna de Paris, sendo ministradas ainda quando esta estava em andamento. A Comuna contribuiu como incentivo para pensar as transformações sociais e como elas poderiam regenerar a sociedade, daí a necessidade de, nas Conferências, serem feitos debates de cunho político e social (SARAIVA, 1995: 42-43).

A vontade de expor ideias progressistas de acordo com os acontecimentos e ideários da Europa do século XIX (como a democracia, a república e o socialismo), de forma tolerante e que visasse a conscientização, encontrou limites quando se deparou com o governo constitucional. Para Antero, o embate fundamentava-se numa ordem social em

\footnotetext{
${ }^{4}$ A Questão Coimbrã foi o conflito que contrapôs a tradicional escola de crítica literária defendida por Antônio Feliciano de Castilho, à poesia revolucionária defendida por Antero.
} 
que havia os progressistas e os conservadores, no entanto, o governo paradoxalmente tido como liberal, tentava inibir novas ideias e aspirações, favorecendo o que lhe era seguro, o conservadorismo.

Diante de V. Ex. ${ }^{a}$ estavam, dum lado, alguns homens que se ocupavam serenamente, com respeito, com moderação extrema, de tirar as últimas conclusões aos princípios liberais; do outro lado a opinião dos ultramontanos (...). V. Ex. ${ }^{\text {a }}$, que é liberal, o que fez? Pôs, como liberal, o seu liberalismo ao serviço dos ultramontanos (...)! (QUENTAL, 1982: 306).

Os jornais conservadores aproximavam o debate proposto pelos conferencistas aos acontecimentos que fragilizavam a ordem europeia (SARAIVA, 1995: 44). Não que estivessem errados, mas o problema maior era o receio de como as problematizações de ideias progressistas iriam abalar a ordem da sociedade portuguesa. Antero propôs um debate em prol do esclarecimento para que juntos e de forma racional a sociedade pensasse meios de solucionar os problemas do atraso português, sua intenção não era declarar a guerra social e sim promover a evolução pacífica, embora os conservadores não entendessem dessa forma.

Para defender-se das acusações dos "ultramontanos",", o letrado declarou as intenções que levaram os intelectuais a abrir o debate público nas Conferências, os jovens pretendiam "avisar o espírito público da necessidade de considerar aqueles problemas" sociais, políticos e religiosos,

(...) convidá-lo a refletir, com serenidade e imparcialidade, nas soluções que pensadores eminentes têm proposto; conjurar as tempestades possíveis de amanhã, por meio do estudo e da tolerância de hoje; apelar para a concórdia de todas as vontades leais, num pensamento de liberdade, de conciliação, de exame (QUENTAL, 1982: 307).

Nesse sentido, Antero aproximava as finalidades das Conferências às da Internacional. Como esta, as Conferências Democráticas supostamente chegariam a uma resolução comum, através de intelectuais que defendiam correntes diferentes, mas que

\footnotetext{
${ }^{5}$ Este termo utilizado por Antero, muito provavelmente está relacionado às suas concepções sobre os desdobramentos históricos originários do pós-Revolução Francesa, tal que o letrado identificava os conservadores como ultramontanos, estes eram os burgueses centralizadores da monarquia constitucional que havia feito de forma incompleta a revolução social.
} 
estavam dispostos ao debate e ao consenso. Quanto ao partidarismo, não era motivo de grandes problematizações, pois os transformistas do governo fusionista enfatizavam a questão do atraso português para conseguir o consensualismo, e isso os intelectuais também faziam (RAMOS, 1992: 519). A diferença significativa é que estes visavam uma revolução moral e relativa à consciência, não apenas o materialismo.

A revolução nos moldes da luta operária não era viável em Portugal, não havia base para um movimento de massas. "Assim, a política alternativa tinha de vir de uma educação dos espíritos, de organização doutrinária”. O espírito crítico frente às táticas transformistas era a efetiva oposição feita pelos letrados (RAMOS, 1992: 519). Restava aos intelectuais agirem conforme as circunstâncias específicas de Portugal, através de uma nova educação, promovendo a organização da opinião pública como forma de combate político.

Pelo espírito científico, a luta teria que ser travada no plano das ideias, almejavase a discussão e não o combate. As sociedades o são como podem ser, faz parte da sua realidade concreta, não adiantando empreender ataques às instituições passadas e sim reconhecer a "fatalidade social" através da crítica que, por si só, garante o progresso pela conscientização (RAMOS, 1992: 518) da necessidade de mudança.

A intenção dos letrados era de elevar a moral da população, o que não fugia da natureza política, inseparável da conjuntura internacional que se revelava como a crença definitiva na concretização revolucionária. Os intelectuais, em conjunto com a Internacional, lutavam contra a política liberal dominante que havia se mostrado insuficiente em termos da justiça igualitária. A maioria dos letrados portugueses moviase em favor da instituição da República Universal, Federativa e Social (CATROGA, 1998: 101-103).

O Federalismo defendido por Antero não era fundamentado somente na teorização característica do século XIX, o letrado buscou na história portuguesa comprovações de que o Federalismo, mesmo em "sua forma" medieval, atendia às necessidades sociais, políticas e até mesmo às de progresso.

Antero de Quental definiu a história medieval portuguesa como sendo um período de grandeza, com "espírito de independência local e originalidade de gênio inventivo". Ressaltou ainda que:

(...) O instinto político de descentralização e federalismo patenteia-se na multiplicidade de reinos e condados soberanos, em que se divide a 
Península, como um protesto e uma vitória dos interesses e energias locais, contra a unidade uniforme, esmagadora e artificial [absolutismo] (QUENTAL, 1979: 141).

Para o letrado, os três fenômenos capitais que extinguiram a liberdade local e o gênio dos ibéricos foram iniciados e fortalecidos a partir do final do século XVI, respectivamente, cada qual refletiu três dimensões, uma moral, uma política e uma econômica. A moralidade foi afetada pela transformação do cristianismo em instituição através do Concílio de Trento; as liberdades político-locais cederam à centralização do absolutismo; e a formação de uma classe mercantil portuguesa não pôde se concretizar devido ao espírito heroico oriundo das conquistas ultramarinas (QUENTAL, 1979: 149). Esses fenômenos agrupados compreenderam aspectos da vida social como o pensamento, a política e o trabalho.

O processo da decadência portuguesa iniciado no século XVI era o oposto das nações que saiam na vanguarda da civilização. Nessas nações predominaram a liberdade moral dada pela Reforma ou pela filosofia, a ascensão da classe média progressista e a indústria moderna que transformava as forças de produção e do comércio.

\footnotetext{
Ora, a liberdade moral, apelando para o exame e a consciência individual, é rigorosamente o oposto do catolicismo do Concílio de Trento, para quem a razão humana e o pensamento livre são um crime contra Deus: a classe média, impondo aos reis os seus interesses, e muitas vezes o seu espírito, é o oposto do absolutismo, esteado na aristocracia e só em proveito dela governando: a indústria, finalmente, é o oposto do espírito de conquista, antipático ao trabalho e ao comércio ${ }^{6}$ (QUENTAL, 1979: 150. Grifos do original).
}

Nesses termos, creio poder afirmar em Antero a tentativa de conciliar tradição e modernidade. $\mathrm{O}$ autor entendia que as instituições políticas de seu tempo foram culturalmente construídas, que faziam parte do imaginário e da identidade nacional. Entretanto, as instituições absolutistas e as revoluções liberais que construíram monarquias constitucionais falharam com as reformas socialmente justas, mantiveram

\footnotetext{
${ }^{6}$ Por esta analogia entende-se o porquê dos ultramontanos terem tamanho receio quanto às ideias debatidas nas Conferências.
} 
Portugal atrasado em relação aos demais países que o letrado tinha por civilizados. Esses países, aos quais Antero recorreu como referências na comparação histórica, ainda o eram quanto ao socialismo contemporâneo, à ciência e ao progresso.

A geração de 70 reconhecia o atraso, queria despertar o país no que tange à moral e à mentalidade, pois a noção de que Portugal estava atrasado já havia deixado os políticos sobressaltados, agindo, sobretudo, no desenvolvimento material desde meados do século. No entanto, e de forma geral, transformações institucionais são projetadas, pensadas, imaginadas e criadas a partir das atividades dos intelectuais (NATÁRIO, 2008: 104).

Antero pensou a superação da decadência portuguesa nos conformes de sua teoria socialista revolucionária e universal. Seria necessário opor à monarquia centralizadora a federação republicana para que os grupos autônomos pudessem dar vida à municipalidade de forma democrática. Somente com a república ter-se-ia reformas práticas, populares e niveladoras, ou seja, coletivas e orgânicas. Era preciso opor, também, à ociosidade industrial o trabalho livre, a indústria do povo, para o povo e pelo povo, esta não seria dirigida pelo Estado, mas sim direcionada de forma espontânea e organizada, de maneira solidária e equitativa (coletivismo), sem a anarquia da concorrência. Fazendo isso, estaria Portugal indo ao encontro do socialismo contemporâneo e ao futuro. Assim seria a regeneração, verdadeira revolução, sem guerra, pelo caminho da paz, da ordem e da liberdade verdadeira (QUENTAL, 1979: 170).

Entrementes, as teorias revolucionárias foram de grande importância para o letrado construir e fundamentar seu pensamento político, além de apresentarem respostas às contradições sociais instituídas historicamente, portanto elas tinham que ser articuladas aos fenômenos dados pela história, pois esta era o caminho para o entendimento da realidade. Nesses termos, e na perspectiva de Antero, a história pode ser interpretada como a porta de entrada para o entendimento das contradições reais. Essencialmente, foi por meio desses dois princípios, história e teorias científicas, que o letrado desenvolveu suas críticas e propunha, ou melhor, enxergava num sentido progressista, o socialismo como o fim último de uma história que alcançaria a justiça social.

No limite, e apesar de Antero de Quental ter se contraposto à vertente ultrarromântica no final da década de 1860, principalmente na chamada Questão Coimbrã, ele estava inserido numa sociedade em que o romantismo ainda era vigente e, talvez por isso, o autor apresentasse características típicas de um romântico. "A consciência histórica provinha da diferenciação e continha uma referência à 
diferenciação: o romântico sabia que era romântico na medida em que não queria repetir modelos" (SALDANHA, 1992: 579).

Atribui-se a isso o fato de Antero ter escrito as Causas da decadência dos povos peninsulares em 1871, a identificação da decadência portuguesa estava intimamente relacionada com a ideia de ruptura e com a formação de uma consciência histórica que, com o direcionamento das teorias científicas, levaria ao novo, à nova sociedade.

Tendo em vista esses dois pilares metodológicos do pensamento anteriano, é possível compreender o porquê de os anos entre 1870 e 1873 terem sido os de maior engajamento político do letrado. A Internacional assumia a frente de uma organização pautada nas teorias revolucionárias; a Comuna de Paris (1871) constituía-se na história como um indicativo de que a Revolução era e estava se fazendo possível; os jovens da Geração de 70 propunham o debate dessas questões e das que eram de ordem nacional; e Antero de Quental se colocava como um dos principais agitadores e formadores da opinião pública por meio de seus artigos e panfletos. Em sua carta autobiográfica de 1887, quatro anos antes de seu suicídio e talvez num momento de maior pessimismo, "o velho" Antero descrevia como essas circunstâncias históricas refletiam no pensamento e na prática política "do novo" Antero:

[...] O que é certo é que, revestido com essa armadura mais brilhante do que sólida, [Antero se referia ao que ele chamou de 'espírito moderno', como as leituras que ele fez de Michelet e Proudhon] desci confiado para a arena: queria reformar tudo, eu que nem sequer estava ainda a meio caminho da formação de mim mesmo! Consumi muita atividade e algum talento, merecedor de melhor emprego, em artigos de jornais, em folhetos, em proclamações, em conferências revolucionárias: ao mesmo tempo que conspirava a favor da União Ibérica, fundava com a outra mão sociedades operárias e introduzia [...] em Portugal a Associação Internacional dos Trabalhadores [...] e tive a minha hora de vã popularidade (QUENTAL, 1974: 132).

Mesmo tendo sido escrita em seus últimos anos de vida, ele buscou retomar seus passos na juventude e as grandes questões desse período. Tratava-se, então, de um intelectual sedento por novos conhecimentos e ansioso por quebrar a ordem injusta num meio que lhe dava oportunidade para tal, um intelectual que buscava a ruptura e, neste sentido, um letrado romântico. Antônio Pires, analisando a juventude do poeta, identifica 
esta fase anteriana como a de quem reage ao seu meio social e que visa adaptá-lo a si próprio, não o inverso. E ainda ressalta, “[...]. Daí que seja um período em que se levantem conflitos para resolver problemas, daí "o querer reformar tudo"” sem “"estar a meio caminho da formação de si próprio"” (PIRES, 1992: 58).

No entanto, as mesmas circunstâncias históricas que fizeram com que o letrado se apoiasse numa teoria socialista, contribuindo para o exercício de tamanha atividade política e intelectual, que pareciam confirmar a concretização da Revolução, podem ter sido também a causa do pessimismo de Antero, principalmente após 1873, quando os sintomas de pessimismo começaram a ser identificáveis.

$\mathrm{Na}$ verdade, ao que tudo indica, tal pessimismo do autor originou-se em um processo acumulativo de decepções intelectuais e pessoais. Em 1871, as Conferências Democráticas do Casino foram proibidas e a Comuna de Paris foi derrotada; em 1872, faltavam recursos para a publicação do periódico O Pensamento Social ${ }^{7}$ (RAMOS, 1992: 508-509), além do fato de a sede da Primeira Internacional ter sido transferida para Nova Iorque, para longe do movimento operário europeu; e, em 1873, Antero recebeu a notícia de que seu pai havia falecido. Após esta notícia ele partiu para seu lugar de origem, para a ilha de São Miguel, onde se manteve afastado por aproximadamente dois anos.

O sentido histórico que antes havia sido interpretado como evolucionista, que caminhava para a justiça, naquele momento dava sinais de que as aspirações e os fatos revolucionários estavam regredindo. No entanto, Antero ainda se mantinha ou tentava se manter firme junto ao ideal socialista. No mesmo ano de 1873, ele escrevia para Oliveira Martins ${ }^{8}$ que, apesar das dificuldades: "Nada d'isto altera ou enfraquece o oto de obediencia que fiz nas aras da Revolução, pondo-me todo e tal qual sou, defeitos e qualidades, força e fraqueza, ao serviço da grande ideia. [...]. Tomei a Cruz e hei de morrer debaixo d'ella ou em cima déella, mas sem a largar"9 (QUENTAL, 1921: 244245. Grifos: em itálico do original e em negrito da autora).

O motivo pelo qual o letrado escrevia estas frases de tensão, mas também de afirmação, foi sua proposta de escrever o Programa para os Trabalhos da geração nova,

\footnotetext{
${ }^{7}$ Para Rui Ramos, o periódico era doutrinário e mantinha o princípio de que as instituições sociais teriam que provir da consciência humana, daí a necessidade de ampliar seu acesso. A publicação do periódico chegou a ser interrompida, mas, ao voltar, adquiriu um teor mais popular e de preço mais acessível. Entretanto, vale salientar que, sem considerar este período de interrupção, o periódico veiculou desde fevereiro de 1872 até outubro de 1873.

${ }^{8}$ Joaquim Pedro de Oliveira Martins (1845-1894) foi amigo próximo de Antero de Quental, como letrado teve significativa contribuição para as teorias revolucionárias e para a História de Portugal, entre suas principais obras estão A Teoria do Socialismo e História de Portugal.

${ }^{9}$ Grifo nosso.
} 
uma elaboração analítica e de cunho revolucionário, que contemplaria sua visão sobre as ideias e instituições numa perspectiva filosófica. Entretanto, o Programa ficou inacabado e foi destruído por ele em 1875 (SALDANHA, 1992: 581).

Mesmo que intimamente, nas cartas trocadas com Oliveira Martins, Antero assumisse de forma rigorosa sua dificuldade em elaborar textos teóricos e revolucionários, na esfera pública "tomou a cruz" por meio de seus textos publicados, transparecendo um intelectual fortemente seguro do que queria. Em suma, a questão principal na relação entre o letrado e o socialismo, tanto em nível pessoal como no público, era que, apesar das dificuldades, ele se manteve firme em seu ideário.

Este comprometimento de Antero pode ser averiguado nas palavras de Antônio Sérgio ${ }^{10}$ que, no limite, era partidário dos ideais do letrado:

Pois não é incontestável [...] que essa série de textos (que vai da juventude até quase à morte) define uma constante da meditação de Antero, do seu socialismo anarquista? [...]. O alvo que ele visava era uma remodelação de fundura ainda que não visse com nitidez bastante os meios adequados para lá chegar (SÉRGIO, 1980: 349-350. Grifos do original).

Muito provavelmente Antero sentia a falta desses meios adequados já em 1873, quando na mesma carta endereçada a Martins sobre o Programa escreveu:

Sabe o que me parece ás vezes? é que sinto mover-se no fundo mais íntimo do meu $e u$ pensante, n’aquele fundo que já não é $e u$ mas o espirito humano, uma ideia imensa, toda uma Filosofia, que não é um sistema, mas a mesma ideia histórica da humanidade, perseguida, entrevista, esquivada, presentida através de todos os sistemas, de todas as religiões, de todas as revoluções... Depois trevas! Olho para as páginas em que pretendo condensar essa ideia, e só encontro verbalismo, abstrações, eloquência ás vezes, mas em tudo aquilo um não sei [...] de estéril! Parece-me que tudo aquilo é imaginação oca, e que cada vez me afasto mais da realidade real $^{11}$ (QUENTAL, 1921: 244. Grifos: em itálico do original e em negrito da autora).

\footnotetext{
${ }^{10}$ António Sérgio (1883-1969), em Portugal foi político e pedagogo, como intelectual foi influenciado pelo socialismo proudhoniano e, assim como Antero de Quental, seu pensamento priorizava questões sobre história e mentalidades.

${ }^{11}$ Grifo nosso.
} 
Este autotestemunho resume e deixa transparecer muito do que foi desenvolvido até aqui sobre o pensamento anteriano. Quando o autor aproxima o seu " $\mathrm{eu}$ pensante" do "espírito humano" deixa clara a valorização do seu humanismo, do seu eu/universal, uma "ideia imensa". Não se tratava de um sistema, mas de sistemas que resultavam na ideia histórica, ponto de vista este muito similar às ideias que Antero, até aquele momento, havia proposto em suas publicações. A compreensão e o enquadramento político e econômico de uma sociedade pluridimensional, eis os sistemas que o letrado estava se referindo, eis o resultado da história. E sobre o que estava desenvolvendo, o letrado qualificava como 'estéril', pois estava distante da "realidade real", dos sistemas, da história, das bases que até aquele momento haviam formado fundamentalmente seu pensamento. Era uma fase de crise intelectual, de pessimismo, a história não condizia mais com suas aspirações, com sua pretendida "Philosophia".

Além da crise teórica, também no âmbito prático Antero de Quental encontrou motivos para que seu pessimismo florescesse. Pouco antes de partir para Ponta Delgada em 1873, coube a Antero escrever o programa da frente União Democrática Portuguesa. Neste projeto, seriam propostos e desenvolvidos muitos dos princípios defendidos pelo letrado.

A União aspira a constituir, no terreno da Razão e da Justiça em que levanta o seu programa, um partido em que as classes rivais e os interesses antagônicos da sociedade atual possam dar-se as mãos, n'um comum proposito de conciliação, liberdade e reforma progressiva para realizarem a harmonia de todos os interesses, racionalmente definidos e justamente equilibrados, e a conversão gradual das antigas classes n'uma nova sociedade, composta só de trabalhadores livres e iguais (QUENTAL, 1996: 57).

A tolerância, a comunhão, a reforma progressiva de base racional e a aliança entre os interesses rivais ainda fazia parte do seu pensamento. Antero, mesmo com a sede da Internacional em Nova Iorque, e mesmo após a saída de Bakunin, manteve seu compromisso e admiração com o princípio que antes vigorava nos Congressos da Associação Internacional dos Trabalhadores, o debate entre as diferentes perspectivas para promover a emancipação proletária.

Preocupado em manter um plano pragmático e eficiente, Antero anexou o programa numa carta a Oliveira Martins para que o amigo desse um parecer sobre o 
conteúdo. "Leia pois isso com caridade; e, artigo por artigo, ponha o seu visto, acrescentando o que entender que deve ser acrescentado [...] para que tenhamos alguma coisa sólida sobre que deliberar" (QUENTAL, 1996: 54). Apesar do esforço do letrado, o programa não foi adiante, pois seus antigos amigos revolucionários não o aceitaram (SARAIVA, 1995: 60). Entretanto, a recusa do programa serviu para reafirmar o que Antero sentia quando escreveu sobre o Programa para Martins:

Encarregado de redigir um projeto que servisse de base à discussão do Programa da União Democrática, fiz isso que lhe envio, e onde transparece ao mesmo tempo a minha boa vontade e a minha incompetência. [...]. Que pensará V. [...] d'um metafísico que cada vez conhece mais a sua insuficiência p. ${ }^{a}$ homem político? (QUENTAL, 1996: 54)

Mais uma vez o letrado deixava transparecer o seu empenho e boa vontade, ao mesmo tempo em que se colocava como incapaz. Mesmo confiante em seu sentimento revolucionário, havia em Antero uma insegurança que, principalmente a partir de 1873, tendia a persistir. As bases circunstanciais, que ele acreditava serem propícias para uma revolução próxima, estavam se esvaindo e, com elas, o otimismo de um amante das aspirações justas e igualitárias, enfim revolucionárias.

Antero expressou seu romantismo mais característico quando se manteve fiel a seus princípios morais, sociais e justos, fossem eles manifestados em seu ideário ou no plano metodológico no qual aliava sempre experiência histórica e teorias revolucionárias. Mesmo quando as condições não se mostravam mais favoráveis, seu comprometimento era de tal magnitude que fazia com que o letrado por vezes exigisse demais de si próprio. Afinal, a mudança se fazia necessária, as contradições histórico-sociais não poderiam continuar, mas onde achar a resposta quando as esperanças teóricas e factuais se esvaíam? Essa questão emocional muito provavelmente contribuiu para o seu pessimismo, e continuou até seu suicídio em 1891.

$\mathrm{Na}$ perspectiva anteriana, o socialismo constituía-se através da história como resposta às contradições sociais, à miséria e à ineficaz política e economia do regime burguês. Foi a partir do avanço teórico/prático do socialismo, principalmente na esfera internacional, que a construção do pensamento político anteriano se fundamentou. Ele enxergou as contradições sociais como um fenômeno universal, por isso Antero pensou o socialismo de uma forma cosmopolita, que correspondesse às aspirações de todos os 
que eram oprimidos socialmente. Esse tipo de concepção dava sentido ao seu humanismo que era divulgado pelo seu esforço para a elevação pacífica de uma consciência social e nos seus textos de conteúdo moral.

Talvez por isso Antero não tenha conseguido se limitar à questão nacional, esta, em seu pensamento político, serviu como base argumentativa para justificar a eminência do socialismo. A questão nacional foi exaltada por Antero em sua forma medieval, uma sociedade descentralizada, de gênio inventivo e de liberdade local, características que validavam seu ideal de Federação. Entretanto, indubitavelmente, o sentimento do atraso português frente outras nações europeias foi um dos fatores que impulsionaram o letrado a pensar como pensou, que colaborou para que ele pensasse meios de se instituir o nivelamento político, econômico e social, resultando, assim, em um pensamento moral e universal.

A Revolução, apesar de ser racionalizada pelas teorias revolucionárias, acima de tudo teria que ser orgânica, de modo que as reformas institucionais respeitassem e fossem condizentes com os diferentes interesses sociais e que estabelecesse a igualdade de condições. Na perspectiva anteriana, assim teria que ser constituído o socialismo, para além de uma proposição política, Antero de Quental interpretava este ideário com a certeza de que ele era uma demanda histórica. Afinal, a própria história tendia a confirmar a necessidade de mudança, de uma revolução consciente, justa, igualitária e inclusiva. A reflexão por meio dos fatos históricos era o caminho para a elevação da consciência popular e, portanto, o caminho pacífico para a verdadeira reforma social. Assim construiu-se o pensamento político de Antero de Quental, visando reformas políticas, econômicas e sociais com base no que o letrado tinha por moralmente democrático e republicano, ou seja, o socialismo.

Entretanto, na medida em que Antero de Quental foi sendo "traído pela história", quando esta não mais correspondia às suas aspirações revolucionárias, o letrado se deixou levar pelo pessimismo. O Antero ativista, teórico e propagador revolucionário enfraqueceu, mas manteve-se firme em seu sentimento moralmente justo, tensão esta que muito provavelmente perdurou durante toda a sua vida.

Advogado, poeta, teórico político e tipógrafo, tudo isso foi Antero, versátil e disposto a ampliar seu conhecimento, o letrado desenvolveu uma sensibilidade e personalidade que catalisava as tensões do mundo à sua volta e que refletiam no seu $e u$ pensante. Disposto a mudar o mundo nos conformes de seus ideais construídos teórica e praticamente, Antero acreditava no que vivia, no que a histórica demonstrava, acreditava 
que existiam contradições sociais e que seria possível progredir para a igualdade e para a justiça. Eis o que representa Antero de Quental para a história, um amante da humanidade, um exemplo de quem pensa e vive a revolução. Foi vencido pelo pessimismo que o levou ao suicídio em sua maturidade, mas que já se manifestava em seus anos de formação aqui perscrutados. Sua luta por justiça social, no entanto, pode, ainda, ser forte inspiração para pesquisadores e ativistas políticos, daqui a importância de continuar lendo e divulgando Antero de Quental.

\section{Fontes}

COELHO, Adolfo (1984). O que foram as Conferências do Casino. In: MEDINA, João. As Conferências do Casino e o Socialismo em Portugal. Lisboa: Publicações Dom Quixote.

QUENTAL, Antero T. de (1982). A política do socialismo. In: SERRÃO, Joel. Prosas Sócio-Políticas: publicadas e apresentadas por Joel Serrão. Lisboa: Imprensa Nacional - Casa da Moeda.

(1982). Carta ao Ex. ${ }^{\text {mo }}$ Sr. António José D’Ávila: Marquês D’Ávila, presidente do conselho de Ministros. In: SERRÃO, Joel. Prosas Sócio-Políticas: publicadas e apresentadas por Joel Serrão. Lisboa: Imprensa Nacional - Casa da Moeda. (1921). Cartas de Anthero de Quental. Coimbra: Imprensa da Universidade. (1979). Causas da decadência dos povos peninsulares. In: SERRÃO, Joel. Liberalismo, socialismo e republicanismo. Lisboa: livros Horizonte. (1982). O Congresso Internacional na Haia. In: SERRÃO, Joel. Prosas SócioPolíticas: publicadas e apresentadas por Joel Serrão. Lisboa: Imprensa Nacional - Casa da Moeda.

(1982). O que é a Internacional (O socialismo contemporâneo, O programa da Internacional, Organização da Internacional e Conclusão). In: SERRÃO, Joel. Prosas Sócio-Políticas: publicadas e apresentadas por Joel Serrão. Lisboa: Imprensa Nacional - Casa da Moeda.

(1974). Poesia e prosa: sonetos completos, poemas e prosa escolhidos. São Paulo: Ed. Cultrix.

(1982). Teoria do Socialismo. In: SERRÃO, Joel. Prosas Sócio-Políticas: publicadas e apresentadas por Joel Serrão. Lisboa: Imprensa Nacional - Casa da Moeda.

\section{Referências Bibliográficas}

CATROGA, Fernando (1992). História e Revolução em Antero de Quental. Revista Guimarães. Portugal, n. 102, pp. 145-201.

(1998). Positivistas e Republicanos. In: TORGAL, Luís R; MENDES, José M. A.;

CATROGA, Fernando. História da História em Portugal sécs. XIX - XX. Lisboa: Temas e Debates, pp. 101-134. 
MEDINA, João (1984). As Conferências do Casino e o Socialismo em Portugal. Lisboa: Publicações Dom Quixote.

NATÁRIO, Celeste (2008). A situação de Portugal na Europa no final do século XIX e início do século XX: a Geração de 70. Revista Estudos Filosóficos: Universidade do Porto. Portugal, n. 1, pp. 100-109.

NEMI, Ana Lúcia L. (2009). História, memória e política na segunda metade do século XIX: Portugal e Brasil entre tradição e modernidade. In: VI Colóquio Internacional Tradição e Modernidade no Mundo Ibero-Americano, 2009, Coimbra. Atas do VI Colóquio Internacional Tradição e Modernidade no Mundo Ibero-Americano. Rio de Janeiro/Coimbra: UERJ/Un. Coimbra, pp. 2-26.

PIRES, Antônio Machado (1992). A ideia de decadência na geração de 70. Lisboa: Vega.

RAMOS, Rui (1992). A Formação da intelligentsia portuguesa (1860-1880). Análise Social. Lisboa, vol. 17, pp. 483-528.

RIBEIRO, Maria Manuela Tavares (1998). A Regeneração e o seu Significado. In: MATTOSO, José. História de Portugal: O Liberalismo. (1807-1890). Lisboa: Estampa, pp. 102-103.

SALDANHA, Nelson (1992). Filosofia e consciência histórica em Antero de Quental. Síntese Nova Fase. Belo Horizonte, vol. 19, n. 59, pp. 575-586.

SARAIVA, António José (1995). A tertúlia ocidental: estudos sobre Antero de Quental, Oliveira Martins, Eça de Queiroz e outros. Lisboa: Gradiva.

SERRÃO, Joel (1980). Do pensamento político-social de Antero de Quental (1868 1873). Análise Social: revista do Instituto de Ciências Sociais da Universidade de Lisboa. Lisboa, vol. 16, n. 61-62, pp. 343-361.

(1979). Liberalismo, socialismo e republicanismo. Lisboa: Livros Horizonte.

SILVA, Lúcio Craveiro da (1996). Novas Cartas inéditas de Antero de Quental. Braga: Faculdade de Filosofia de Braga.

Artigo recebido em 04 de agosto de 2016.

Aprovado em 23 de novembro de 2016.

DOI: 10.12957/intellectus.2016.26668 